\title{
CENTRAL BANK'S INFLATION FORECAST AND EXPECTATIONS. A COMPARATIVE ANALYSIS
}

\section{Magdalena Szyszko*}

\begin{abstract}
The question on the inflation expectations management is one of the most important ones from the central bank's point of view. The inflation forecast can be a helpful tool of managing expectations. If it actually is, the interdependences of the inflation forecast and expectations can be observed. The existence of such interdependences opens the field for determining the preconditions that might support expectations formation. The hypothesis assumes that associations of inflation forecasts and inflation expectations depend on the central bank's credibility and consistency in inflation forecast targeting. The research covers the Czech National Bank, the National Bank of Hungary, the National Bank of Poland and Sveriges Riksbank. The research combines qualitative and quantitative methods. The research uses survey-based expectations quantified with probabilistic method. The main finding is that the relatively high level of credibility and consistency in inflation forecast targeting is not sufficient to achieve strong interdependences of inflation forecast and expectations.
\end{abstract}

Keywords: inflation forecasts, inflation forecast targeting, inflation expectations, central bank credibility

JEL Classification: E52, E58, E61

\section{Introduction}

Modern monetary policy focuses on inflation expectations. Central bankers are con-tinuously searching for the tools that would enhance their opportunity to influence inflation expectations. Inflation targeting framework offers it via focussing on numerically set inflation target, producing and publishing inflation forecast, setting floating exchange rate regime, ensuring central bank's independence and transparency. One argues that the central bank's inflation forecast is one of the most important tools of supporting inflation expectations. Empirical research proves that there are interdependences between inflation forecast and inflation expectations. Their strength differs among the countries. There is no obvious reason for such a diversity. That is why the research question of this paper is, whether there are institutional or practical solutions that may enforce the strength of correlation between the inflation forecast and inflation expectations.

The research covers expectations of the less qualified economic agents - namely consumers. They are "secondary readers" of the central bank's news. On the other hand, their economic decisions are crucial for both the economic performance, and for the monetary transmission itself. It has also been proved that consumers do not form their expectations

\footnotetext{
* Magdalena Szyszko, WSB University in Poznan, Finance and Banking Faculty, Poznan, Poland (magdalena.szyszko@wsb.poznan.pl).

The paper presents the results of research financed by the National Science Center

"Interdependences of Inflation Forecasts and Inflation Expectations of Market Participants.

Implications for the Central Banks" (No. 2011/03/B/HS4/03705).
} 
rationally. Therefore, finding out what factors may support their forward-looking attitude is worthwhile.

This choice of consumers' expectations to some extent imposes the research methodology. It also imposes possible factors considered as supportive in terms of shaping the expectations. Intricate aspects of monetary policy are not to be considered. This research covers two factors: central bank credibility (and effectiveness) and central bank consistence in implementing inflation forecast targeting. The research hypothesis assumes that interdependences of inflation forecasts and inflation expectations are higher when (1) the central bank is credible and (2) is consistent in implementing inflation forecast targeting.

The research covers Hungary (the National Bank of Hungary, NBH), Poland (National Bank of Poland, NBP) the Czech Republic (the Czech National Bank, CNB), and Sweden (Sveriges Riksbank, SR). They all operate in inflation targeting framework. Three of them represent young market-oriented economies and the fourth one - the Sveriges Riksbank is one of the most experienced inflation targeters worldwide. Such a choice enables comparative analysis having the Sveriges Riksbank as the reference country due to its practice in implementing inflation targeting (IT), forecasting inflation, and relatively high interdependences of inflation forecasts and inflation expectations of consumers.

The paper is divided into 3 sections. The first one presents the literature overview of the expectation in monetary policy and the forecasts of inflation functions. The second section delivers details on methodology. In the third section the results are presented and commented upon. The paper contributes to the literature on IT and inflation expectations formations. It enables the in-depth comparison between the four countries in question.

\section{Literature Overview}

Expectations are in the center of the central bank's interest as they are the driving factor in modern monetary transmission. Inflation equation (New-Keynesian Phillips curve) is derived from the staggered prices model. It assumes the prices cannot be reset continuously. Each price setter is allowed to change its price at the random chosen moment. The probability of this change in period $t$ is independent of the moment of the last price change and it is also independent across the firms. A firm knows that the change of price may not be possible in the following period. That is why a company while setting its price takes into account the expected average price and the excess demand in the future (Calvo, 1985). Firms changing their prices now do not know when the next change is possible. They consider not only today's conditions but also their expectations on future costs and demand. The explanation why they do not change the prices in any moment varies over time. Initially, the existence of nominal and real rigidities was the bounding factor. The rigidities, described in Neokeynesian stream of literature, were of different origin, the examples of which are found in (Ball, 1990), (Mankiw, 1985). Recent findings refer to sticky information (Mankiw, 2002) and the choice of inattentive behaviour: the producers set the price for their output and optimal time when they do not process any new information (Reis, 2006).

Apart from the inflation expectations, today inflation depends on the output gap. The output gap depends on the real interest rate and the expected economic development. The most commonly applied reaction function of the central banker also refers to inflation expectations. Three basic equations of the modern economic theory are derived from (Galí, 2008), (Goodfriend, 2007). 
The monetary transmission given by the New Neoclassical Synthesis is broadly accepted by the central bankers. It imposes the search for such a framework of monetary policy that enables steering inflation expectations. As summarized in (Woodford, 2003, 15-18) optimizing model implies that private sector behaviour should be forward-looking; hence expectations about future market conditions should be a significant determinant of current behaviour. If the central bank is able to affect expectations, it will have more opportunities to achieve the goals that have been set.

The research on expectations focuses mostly on the expectation formation, their consistency with the inflation target and insensitiveness to changes in current inflation, and the role of expectations in creating actual price dynamics (Łyziak, 2014).

The examination of all the aspects of expectations should be preceded with an assumption on the expectation formation or with their measurement. The theory on expectations formation has evolved and has been reflected in changes of the Phillips curve. The Monetarists proposed expectations' augmented Phillips curve. Formal model of expectations proposed by (Cagan, 1956) assumed that economic agents form their expectations referring to the information the past (adaptive expectations). New Classical Economy highlighted the rationality of expectations (Lucas, 1972). Nowadays bounded rationality or adaptive learning which incorporates learning mechanism in economic model prevail in theoretical analysis. Empirical research confirms that the expectations of economic agents are biased regardless of the territorial scope of the research (Forsells, 2004), (Dias, 2010), (Mitchell, 2007), (Łyziak, 2003). Non-rationality of the expectations (their bounded rationality) justifies the research on the best ways of supporting expectations formation. A number of recent papers focuses on rational inattentive behaviour to explain how nonspecialist form their expectations. Time-constrained consumers optimize their utility and undertake consumption decisions infrequently. The slow diffusion of information among them results from the costs of acquiring information as well as the costs of reoptimization. Facing these costs, a person setting a plan of action for consumption must choose not only what to consume, but also when to plan again. With regards to her consumption plan, between two periods which are in between planning dates, the person is not obtaining any new information (Reis, 2006a). The literature refers also to epidemiological expectations. It argues that the consumers form their expectations taking into consideration professional forecasts distributed by the media. They do it imperfectly, as they need time to absorb the economic content of news stories, so it takes some time for economic conditions to change (Carroll, 2003). The expectations formation process is analogous to the transmission of a disease which needs a contact with a common source of infection in a population. Such a source of infection for consumers' inflation expectations are media. The news spreads slowly among the economic agents. Carroll's epidemiological expectations theory is supported (or partially supported) by the empirical findings for the USA (Pfajfar, 2013), Germany (Lamla, 2012) and for China (Lei, 2015). Other studies search for possible enlargement of original Carroll's findings and examine whether the volume and content of the media signal may affect consumers forecast accuracy (Lama, 2014).

The discussion on expectations focuses also on their measurement. As they are directly unobservable, the expectations can be inferred from a macroeconomic model (the assumption on the way how they are formed is needed) or measured empirically on the basis of financial market data (prices and yields of bonds, for example) or the surveys. One distinguishes direct and indirect measurement and testing of expectations. Direct 
tests make use of survey data on expectations, and the indirect tests focus on cross equation parametric restrictions of the expectations formation models when combined with a particular parametric economic model (Pesaran, 2005). Indirect methods are based on the analysis of the influence that expectations exert on economic environment in which they are formulated. The expectations are deduced from the behaviour of economic system. (Tomczyk, 2010). The lack of generally accepted pattern of expectations formation process is a significant drawback of this approach.

Survey based approach to quantification of expectations is broadly accepted. Its advantages are: the forecast accuracy (specialists' and consumers' expectations are better predictors of a year ahead inflation), there is no need of any a priori assumption (which is needed in a model based forecasts), there is no contamination of the data by transaction costs, risk premium, and taxation (which is characteristic of financial assets prices) (Ang, 2007). The survey based expectations are also used in this study. It is also justified by the choice of the consumers as a reference group.

It is widely acknowledged that inflation targeting is monetary policy strategy that fits to the monetary theory and is designed to manage expectations. This framework encompasses five main elements described in (Bernanke, 2001). Central banks implementing inflation targeting are not obliged to focus their decision-making process on any variable. It is the information inclusive strategy in which many variables are used in order to set the policy instruments. However, the central bank may seek to facilitate the decision-making process and focus on inflation forecast. Producing and revealing inflation forecast is the immanent part of fully-fledged inflation targeting. The inflation forecasts enable forward-lookingness of monetary policy which is an important feature in the light of monetary policy lags existence. It may also simplify the discussion of the monetary policy committee (MPC). The forecast incorporates a set of historical and current data including expectations. One variable - the forecast - includes the idea of analysing various data. Instead of discussing them one by one, the MPC may discuss only (or mainly) the forecast (Szyszko, 2011).

The central bank may produce its inflation forecast on different interest rate assumption. The most common solution is the assumption on the constant bank's rate throughout the forecast horizon. Such a forecast is called conditional. Instead of constant rate assumption, conditional forecast can be produced with the assumption that the rates change according to market expectations. The forecast is called unconditional when the interest rates are endogenized due to reaction function incorporation to the model or application to specific targeting rule. Possible option of interest rate assumption are broadly discussed in Svensson (2003).

Focussing on inflation forecast in decision-making and communication makes the inflation forecast a specific (as not formally established) intermediate goal. It has the proprieties of properly set intermediate goal (correlation with the final goal, controllability by the central bank, transparency) (Debelle, 1997), (Svensson, 1997). If the central bank uses the forecast as an intermediate target, it implements inflation forecast targeting (IFT). Forecast targeting is perceived as a simple policy rule that involves the commitment to a particular decision procedure for monetary policy and distinctive approach to communication policy (regular publication of quantitative projections together with extensive discussion of the reasoning underlying these projections) (Woodford, 2012). It is also argued that subscribing the function of an intermediate target to the inflation forecast simplifies implementing and monitoring monetary policy (Svensson, 1997). While setting 
the monetary policy instrument, the central bank analyses the relation of the inflation forecast to the inflation target in monetary policy horizon. The interest rate should be set so as to make the inflation forecast equal to the inflation target in monetary policy horizon. If the inflation target is above (below) the target, the main rate of the monetary policy should be raised (lowered). If the central bank produces unconditional forecast with endogenous interest rates, the central bank's reaction function implies such policy path (set of current and subsequent interest rates) that should bring the inflation (and the forecast) to the target in monetary policy horizon. If the forecast is conditional (for example on the constant central bank rate), the MPC uses the rule of thumb to adjust the rates. Ex-post inflation may differ from the targeted level because of the forecast errors (Svensson, 1996).

Supporting the decision-making procedure of the central bank is an internal function of the forecast. In the context of expectations formation, the most important one is its external function. It is fulfilled if the forecast is published. While making decisions, economic agents are taking into consideration the whole expected interest rate path. The forecast, especially when the policy path is revealed, shows not only the next step of the MPC but possible subsequent actions as well. Inflation forecast can also anchor expectations when the inflation target is temporarily missed. It can serve as such a temporary anchor, especially in situations where the target is missed because of shocks that are out of control of the central bank. Anticipated course of inflation, showed by a credible central bank may limit the expectations' growth (Skořepa, 2003).

The purpose of this paper is to verify whether the interdependences of the inflation forecasts and consumers' expectations depend on (1) central banks' consistency in inflation forecast targeting and (2) its credibility and effectiveness. A brief overview of the literature given above shows that the forecast may be an important component in decision-making of the MPC and a tool that supports expectations formation. The forecast message should be followed by the MPC. It enhances the forecast possible relations with expectations. If the central bank's information is to be taken into consideration by the public, the central bank itself should be credible. This is connected with the second part of this paper's hypothesis. Quite simple but capacious definition of credibility says that the central bank is credible if people believe that it will do what it said (Blinder, 2000). Central bank's credibility is unobservable directly. There is no accepted measure of credibility. Its measurement refers to the central bank's effectiveness or the public beliefs in central bank's ability to fulfill its obligation. Three credibility measures relying on the deviation of the past inflation (or inflation expectations) and actual inflation are applied here. Their extension is the Kia and Patron formula described in the next section.

\section{Research Methodology}

The research covers 4 countries. Details on the sample are given in Table 1 .

Methodology covers 2 stages, each including several steps (Table 2). The division into two stages is the result of the research outline: during the first stage the existence of the interdependences of inflation forecasts and consumers expectations was verified. The results confirm the existence of such relations of weak to moderate strength. The results and methodology of this research have been already described in Szyszko (2015) and is not presented here in detail (outlined in Table 3). The second stage of the research is crucial for verifying the hypothesis of this paper. It covers 2 steps. The first one consists in assessing the central bank's credibility. The measures that are applied are listed in Table 4. 
Table 1 | Sample Description

\begin{tabular}{|l|c|c|c|c|}
\hline Central bank & CNB & NBH & NBP & SR \\
\hline Number of forecasts & 50 & 54 & 33 & 88 \\
\hline Months & 151 & 161 & 125 & 205 \\
\hline Period & July 2002-2014 & August 2001-2014 & August 2004-2014 & December 1997-2014 \\
\hline
\end{tabular}

Source: author

Table 2 | Research Methodology - the Outline

\begin{tabular}{|l|l|l|}
\hline Research stage & \multicolumn{1}{|c|}{ Steps of the research } & \multicolumn{1}{|c|}{ Short description } \\
\hline \multirow{2}{*}{$\begin{array}{l}\text { I stage: } \\
\text { interdependences } \\
\text { analysis }\end{array}$} & 1. Expectations & $\begin{array}{l}\text { Deriving and processing the data } \\
\text { on consumers' expectations }\end{array}$ \\
\cline { 2 - 3 } & 2. Forecast of inflation & $\begin{array}{l}\text { Deriving and processing the data } \\
\text { on inflation forecast }\end{array}$ \\
\cline { 2 - 3 } & 3. Interdependences & $\begin{array}{l}\text { Assessing the correlation between } \\
\text { the inflation forecast and expectations }\end{array}$ \\
\hline $\begin{array}{l}\text { II stage: } \\
\text { interdependences } \\
\text { determinants }\end{array}$ & 4. Credibility/ Effectiveness & $\begin{array}{l}\text { Assessing the central bank's credibility } \\
\text { (effectiveness) }\end{array}$ \\
\cline { 2 - 3 } & 5. Inflation forecast targeting & Central bank's decisions analysis \\
\hline
\end{tabular}

Source: author

The literature gives a vast choice of the credibility measures, three of which have been adopted in the following paper. The first one is a standard measure of credibility and the measure of the central bank's effectiveness as well. It delivers ex-post evaluation of the central bank's declaration on the main goal fulfillment. It is assumed that the central bank is credible when the coefficient is between 0 and 1 . It is consistent with the way how central banks design their goal. Usually it is given with the accepted fluctuation boundary of $+/-1$ p.p. If the mean deviation of actual inflation from the inflation target does not exceed 1, it means that the inflation was within the accepted fluctuation boundary. The higher the coefficient is, the lower is the central bank's credibility.

Second measure is Kia and Patron formula (Kia, Patron, 2004). As it is the exponential function, the increasing deviation of inflation from the inflation target means that the credibility of the central bank decreases faster. The interpretation of credibility here is consistent with the previous measure and refers to fluctuation boundary. The deviation from the target of 1 p.p. implies the value of the formula close to 60.65 points. That is why it is assumed that the central bank is credible when the Kia and Patron formula is between 60 and 100 points.

The last credibility measure is mean absolute deviation of inflation expectations from inflation target. Its interpretation is again in line with the inflation target formulation. The replacement of the actual inflation with inflation expectations distinguishes the measure from the first one. It enables the ex-ante evaluation of the central bank's credibility. The first measure highlights the actual possibility of achieving inflation target (central bank's effectiveness). The third one - economic agents' beliefs in central bank's ability to do so. 


\begin{tabular}{|l|l|}
\hline Data/measure & \multicolumn{1}{c|}{ Description } \\
\hline Expectations & $\begin{array}{l}\text { Survey data on expected inflation are taken from the Business and Consumers } \\
\text { Surveys - The European Commission's survey on business and household } \\
\text { situation. Surveys are held monthly. Respondents answer the question on their } \\
\text { expectations about consumer prices development in the next } 12 \text { months. } \\
\text { They choose one answer out of 5 possible answers; details in: (The Joint, 2007). } \\
\text { The answers to the survey's questions are the starting point for quantifying } \\
\text { inflation expectations using the adjusted Carlson-Parkin probability method } \\
\text { (Carlson, Parkin, 1975), (tyziak, 2003). }\end{array}$ \\
\hline Inflation forecast & $\begin{array}{l}\text { Inflation forecast is published in Inflation Report or equivalent document } \\
\text { on monetary policy. They are published with different frequency, usually } \\
\text { quarterly. The forecast is published on the fan chart, the explicit level } \\
\text { of central path is not necessarily given. This is one of the reasons why } \\
\text { the data on the forecast are encoded in the way consistent with inflation goal } \\
\text { formulation. The relation of the central path of inflation and inflation target at } \\
\text { the beginning of transmission horizon is checked. }\end{array}$ \\
\hline Interdependences \\
measures & $\begin{array}{l}\text { Non-parametric statistics. Under a null hypothesis there is no monotonic } \\
\text { association between inflation forecast results and expectations or the two } \\
\text { variables are independent at } a=0.05 . \text { As the forecast is produced 3-6 times per } \\
\text { year and the expectations are examined monthly, one forecast message may } \\
\text { influence the expectations formation 3 times (lags: } t, t+1, t+2, t+3) \text {. The central } \\
\text { path is repeated for the months following the month when the forecast was } \\
\text { produced. }\end{array}$ \\
\hline
\end{tabular}

Source: author

Table 4 | Credibility Measures and Their Interpretation

\begin{tabular}{|l|l|c|}
\hline \multicolumn{2}{|l|}{ Measure } & Credibility \\
\hline $\begin{array}{l}\text { Absolute deviation of inflation from } \\
\text { the inflation target }\end{array}$ & $\begin{array}{r}|\dot{y}-\pi|, \dot{y} \text { is inflation rate and } \\
\pi \text { is the inflation target }\end{array}$ & $<0,1>$ \\
\hline Kia and Patron formula & $\frac{100}{e^{0,5|\dot{y}-\pi|}}$ & $<60,100>$ \\
\hline $\begin{array}{l}\text { Absolute } \\
\text { deviation of inflation expectations } \\
\text { from the inflation target }\end{array}$ & $\begin{array}{l}|E y-\pi|, E y \text { is inflation } \\
\text { expectations }\end{array}$ & $<0,1>$ \\
\hline
\end{tabular}

Source: author

Two additional remarks on measuring the central bank's credibility should be made. First of all, all the credibility measures given in Table 4 are proxies. Secondly, they refer to the deviation of the actual or expected inflation form the target. In inflation targeting regime, the actual inflation is allowed to temporarily deviate from the target. The central bank ignores shocks to limit its own reaction effects for the real sphere. There are alternative credibility measures like the one comparing inflation factors, described in Inflation Reports with ex-post identified inflation factors (Bulir, Hurnik, Smidkova, 2014). In this research 
central bank's qualification as credible or not credible is less important that credibility comparison of the central banks covered by the examination.

The last step of the research is of a qualitative nature. It verifies whether the central bank really implements IFT. Table 5 presents possible aspects that can be checked here. For the purpose of the following study, only the second aspect described in Table 5 is used. The assessment of the MPC decisions consistency with the forecast depends on the interest rates assumption. When the central bank produces conditional forecast, the relation between the central path of inflation and inflation target in the monetary policy horizon determines next MPC decision. If the central path of inflation is above (below) the target, the interest rates are to be raised (lowered). When the forecasted inflation is within the fluctuation band of the target, any MPC reaction is consistent with the IFT implementation. The central path of inflation at the targeted level means that the rates should remain unchanged. When the central bank produces unconditional forecast with endogenous interest rates, the next MPC step is given explicitly by the policy path. However, there are several possible ways to understand central banks' consistency in IFT implementation (Szyszko, forthcoming). For the purpose of this research, simplified version described above is applied: the central bank is consistent with IFT, if its decisions are not in contradiction to the forecast message. The central bank commitment to IFT depends also on several qualitative factors, including forecast ownership or the MPC members engagement into forecasting procedures.

Table 5 | IFT Implementation Verification

\begin{tabular}{|l|l|}
\hline Feature & \multicolumn{1}{c|}{ Description } \\
\hline $\begin{array}{l}\text { Formal declaration } \\
\text { on the importance } \\
\text { of inflation forecasts }\end{array}$ & $\begin{array}{l}\text { It shows to the public what the declared role of inflation forecast } \\
\text { in monetary policy is. This declaration is just the starting point } \\
\text { as the actual behaviour of policy makers does not always reflect } \\
\text { the declaration. }\end{array}$ \\
\hline $\begin{array}{l}\text { Consistency of the } \\
\text { decision of the MPC with } \\
\text { the inflation forecast } \\
\text { result }\end{array}$ & $\begin{array}{l}\text { The rule of thumb suggests the central bank's decision. The decision can } \\
\text { be derived explicitly (when central bank's rates are endogenized, from } \\
\text { the policy path) or implicitly (when projection is reduced). Both versions } \\
\text { are described above in details. }\end{array}$ \\
\hline Decision timing & $\begin{array}{l}\text { It shows whether the central bank perceives the forecast as the best } \\
\text { information on the future state of the economy; if it does, it makes } \\
\text { decisions consistent with the forecast just after the forecast is made. }\end{array}$ \\
\hline Decision justification & $\begin{array}{l}\text { It shows the main rationale behind the decision on interest rate; } \\
\text { the central bank sends the message on the importance of forecast to } \\
\text { the public if it refers to the forecast message in the justification. }\end{array}$ \\
\hline
\end{tabular}

Note: Consistency of the MPC decisions with inflation forecasts is then expressed by means of the coefficient giving the percentage share of the decisions that are not in line with the forecast results in total number of decisions.

Source: own on the basis of (Szyszko, 2011).

\section{Results and comments}

Empirical results are presented below. Table 6 gives the outline of the first stage of the research results. For all the central banks covered by the examination the null hypothesis on the nonexistence of interdependences of inflation forecast and inflation expectations is 
rejected at $\alpha=0.05$. It means that there is a monotonic relationship of the inflation forecast and the expectations. The strength of the interdependences varies among countries. It is weak to moderate. It is also more remarkable when the lag is longer, which is in line with the epidemiological expectations theory: media need little time to process and publish the message on the central bank forecast but consumers need more time to absorb it.

Table 6 | Interdependences of the Inflation Forecast and Expectations

\begin{tabular}{|c|c|c|c|c|}
\hline & CPR/Exp(t) & $C P R / \operatorname{Exp}(t+1)$ & $C P R / \operatorname{Exp}(t+2)$ & $C P R / \operatorname{Exp}(t+3)$ \\
\hline \multicolumn{5}{|c|}{ CNB } \\
\hline$r_{s}$ & 0.300223 & 0.315742 & 0.323945 & 0.344746 \\
\hline Gamma & 0.278290 & 0.294854 & 0.302782 & 0.319144 \\
\hline$\tau$ & 0.238926 & 0.253425 & 0.260584 & 0.274611 \\
\hline \multicolumn{5}{|c|}{ NBH } \\
\hline$r_{s}$ & 0.406887 & 0.427387 & 0.439394 & 0.436730 \\
\hline Gamma & 0.361664 & 0.381515 & 0.393794 & 0.394843 \\
\hline$\tau$ & 0.304825 & 0.320833 & 0.331060 & 0.331826 \\
\hline \multicolumn{5}{|c|}{ NBP } \\
\hline$r_{s}$ & 0.571530 & 0.590092 & 0.588259 & 0.589018 \\
\hline Gamma & 0.523190 & 0.539947 & 0.537704 & 0.542294 \\
\hline$\tau$ & 0.449249 & 0.463943 & 0.461651 & 0.464771 \\
\hline \multicolumn{5}{|c|}{ SR } \\
\hline$r_{s}$ & 0.602312 & 0.611000 & 0.619806 & 0.626097 \\
\hline Gamma & 0.669290 & 0.680637 & 0.687702 & 0.693563 \\
\hline$\tau$ & 0.483846 & 0.492050 & 0.497928 & 0.502953 \\
\hline
\end{tabular}

Source: author

Table 7 presents details of the second stage of the research - searching for the interdependences determinants. In the light of the measures applied, none of the central banks is credible. Central banks can be ranked according to their credibility. Sveriges Riksbank with the lowest absolute deviation of inflation from the inflation target and deviation of inflation expectations from the inflation target has the highest level of credibility. It is confirmed with the Kia and Patron formula at the level closest to 60 points. The SR is followed by the NBP and the CNB. The difference between Poland and the Czech Republic is not significant. The NBH has the poorest performance in terms of credibility.

The ranking of the central banks' consistency in implementing IFT shows that the CNB followed the message of the forecast in $97 \%$ of decisions while the less consistent central bank of Hungary did not so in almost $1 / 4$ of the decisions. 
The HNB diverges from the other central banks significantly. It is due to the strategy that it implemented: prior to February 2008, it declared to implement inflation targeting but, in fact, it implemented a rather eclectic strategy. It operated within the framework of inflation targeting except for the exchange rate regime. The Hungarian forint rate was fixed to the euro with the accepted fluctuation band of $+/-15 \%$ around the central parity. The majority of the interest rate decisions that were not in line with the forecast message were made prior to February 2008. The NBH inconsistency in IFT implementation can be also observed while considering communication. Even in the months when the forecast is revealed, it is not in the center of the Monetary Council discussion as could be inferred from the abridged minutes of the MPC.

Table 7 | Credibility and IFT Implementation

\begin{tabular}{|c|c|c|c|c|}
\hline Central bank & CNB & NBH & NBP & SR \\
\hline \multicolumn{5}{|l|}{ Credibility } \\
\hline $\begin{array}{l}\text { Absolute deviation of inflation from } \\
\text { the inflation target }\end{array}$ & 1.46 & 1.88 & 1.34 & 1.29 \\
\hline Kia and Patron formula & 55.85 & 49.63 & 54.55 & 56.68 \\
\hline $\begin{array}{l}\text { Absolute } \\
\text { deviation of inflation expectations } \\
\text { from the inflation target }\end{array}$ & 1.29 & 2.27 & 1.25 & 1.10 \\
\hline \multicolumn{5}{|l|}{ Decisions' consistency } \\
\hline $\begin{array}{l}\text { Share of the decisions that are not } \\
\text { in line with the forecast }\end{array}$ & $2.9 \%$ & $24.84 \%$ & $5.00 \%$ & $5.26 \%$ \\
\hline
\end{tabular}

Source: author

In March 2011 the NBH started to produce forecast with endogenous interest rates. However, in contrary to the predominating practice of the central banks, the policy rate path is not made public. In the first Inflation Report where the forecast with endogenous interest rate was presented, the NBH stated that qualitative suggestions concerning the expected direction of policy rate measures will be given. This practice was dropped at the end of 2011 . The fact that the NBH produces interest rate path but refuses to reveal it may interfere with the evaluation of the MPC decisions' consistency. The policy path should be the reference point while assessing it. If it is not revealed, standard rule of thumb referring to the relation of the central path of inflation and inflation target must be applied to assess the decision consistency.

Regardless of the poorest results for credibility and consistency in IFT implementation, it was not the case of the $\mathrm{NBH}$ where the interdependences of inflation forecast and expectations where the weakest. The result for CNB is surprising in the light of relatively good coefficient of credibility and consistency in IFT implementation. Additionally, the CNB proved to be one of the most consistent IFT targeters while considering the other qualitative aspects of IFT implementation (described in Table 5). At the end of the research period, the Bank Board operated close to the nominal boundary of the interest rate, finally touching the zero bound in December 2013. Since then, monetary policy easing has 
been performed through exchange rate channel (verbal and actual intervention on forex). Following the policy path was not possible.

The sample for the CNB covers 50 forecasts. Only 5 out of 50 forecast are conditional. This is a possible reason of weaker interdependences of the forecasts and expectations: here the central path of inflation was compared with inflation forecast. There are two justifications of such a choice. The first one is of a theoretical nature: despite the possible positive effects of publishing interest path, the gains from revealing it are relatively smaller when compared with the publication of the inflation projection itself. It is quite difficult for economic agents to forecast economic development. But once they are given, the forecast of inflation (or broader - macroeconomic forecast), they can much easily predict future level of the interest rates (Brzoza-Brzezina, Kot, 2008). The second reason is of an empirical nature: the interdependences of the forecast and policy path (instead of the central path of inflation) were also calculated in this research. Their strength is moderate (around 0.50) but the sign is counterintuitive: it is positive. Possible explanation here is that the policy path should bring inflation to the inflation target in the monetary policy horizon. It is not always fulfilled, especially at the beginning of monetary policy horizon as the economy needs more time to reach equilibrium (inflation target for inflation).

The other explanation of relatively low results for the Czech Republic is the way in which the inflation target was formulated there up to 2005 when the target for 2006 and next years was announced. The inflation target was represented by the accepted boundary of inflation fluctuation. No central point was given. The possible power of anchoring expectations of such a solution was weaker.

While summarizing the empirical research, it needs to be said that the hypothesis of the paper is not fully confirmed due to the lowest interdependences of inflation forecast and inflation expectations of the CNB. The panel of 4 countries also limits the possibility of the results generalization. However, the research delivers the possibility to compare several features of the central banks in the context of their ability to influence inflation expectations.

\section{Conclusion}

Despite the fact that the results are not unambiguous, the research contributes to the discussion on the factors that are the preconditions for supporting expectations formation of the households. The actual behaviour of the central banker and the consistency with the declarations, here expressed with the central bank credibility and its consistency in the declared IFT implementation, seem to be such conditions. However, it is not enough to be credible and consistent to reach high interdependences of inflation forecast and expectations. The research will be more informative if the sample of the countries under study is extended. The author is currently working on a broader analysis encompassing Romania, England and Norway. There are also other possible factors affecting expectation formation via inflation forecast. They are often of qualitative nature, as the central banks' transparency or transparency of forecasting system itself.

The research result can possibly be affected with the choice of research period. It is quite long and turbulent: it covers episodes of stronger disinflation and higher inflation volatility. During the research period the central banks changed their goals level and applied some additional monetary policy measures. Some of them operated at zero lower bound. Having long-time series usually expose the research on the risk of institutional changes that may affect the sample. 
The difficulty of such research relies also on finding the balance between the factors that are considered and actual capability of the households to gain and process information even by the media.

\section{References}

Ang, A., Bekaert, G., Wei M. (2007). Do Macro Variables, Asset Markets or Surveys Forecasts Inflation Better? Journal of Monetary Economics, 54(4), 1163-1212, http://dx.doi. org/10.1016/j.jmoneco.2006.04.006

Ball, L., Romer, D. (1990). Real Rigidities and Non-Neutrality of Money. The Review of Economic Studies, 57(2), 183-203, http://dx.doi.org/10.2307/2297377

Bernanke, B. et al. (2001). Inflation Targeting: Lessons from the international Experience, Princeton: Princeton University Press. ISBN: 9780691086897.

Blinder, A. S. (2000). Central-Bank Credibility: Why Do We Care? How Do We Build It? American Economic Review, 90(5), 1421-1431, http://dx.doi.org/10.1257/aer.90.5.1421

Brzoza-Brzezina, M., Kot, A. (2008). The Relativity Theory Revised: Is Publishing Interest Rate Forecast Really so Valuable? National Bank of Poland Working Paper Series No. 52.

Bulir, A., Hurnik, J., Smidkova, K. (2014). Inflation Reports and Models: How Well Do Central Banks Really Write? IMF Working Papers 14/91, International Monetary Fund.

Cagan, P. (1956). The Monetary Dynamics of Hyper-Inflation, in Friedman M. ed., Studies in the Quantity of Money, Chicago: University of Chicago Press, pp. 25-117.

Calvo, G. (1983). Staggered Prices in Utility-Maximizing Frameworks. Journal of Monetary Economics, 12(3), 383-398, http://dx.doi.org/10.1016/0304-3932(83)90060-0

Carlson, J. A., Parkin, J. M. (1975). Inflation Expectations. Economica, 42(166), 123-138, http://dx.doi.org/10.2307/2553588

Caroll, C. D. (2003). Macroeconomic Expectations of Households and Professional Forecasters. Quarterly Journal of Economics, 118(1), 269-298, http://dx.doi. org/10.1162/00335530360535207

Debelle, G. (1997). Inflation Targeting in Practice. International Monetary Fund Working Paper No. 35.

Dias, F., Duarte, C., Rua, A. (2010). Inflation Expectations In the Euro Area: Are the Consumers Rational? Review of World Economics, Springer, 146(3), 591-607, http://dx.doi.org/10.1007/ s10290-010-0058-6

Forsells, M., Kenny, G. (2004). The Rationality of Consumers' Inflation Expectations: SurveyBased Evidence for the Euro Area. Journal of Business Cycle Measurement and Analysis, 2004(1), 13-41, http://dx.doi.org/10.1787/jbcma-v2004-art3-en

Galí, J. (2008). Monetary Policy, Inflation, and the Business Cycle, An Introduction to the New Keynesian Framework. Princeton: Princeton University Press.

Goodfriend, M. (2007). How the World Achieved the Consensus on Monetary Policy. The Journal of Economic Perspective, 21(4), 47-68, http://dx.doi.org/10.1257/jep.21.4.47

Kia, A., Patron, H. (2004). Market-Based Monetary Policy Transparency Index, Risk and Volatility The Case of the United States. Carleton University Economic Papers, No. 7.

Lama, M. J., Lein, S. M. (2014). The Role of Media for Consumers' Inflation Expectation Formation. Journal of Economic Behavior and Organization, 106, 62-77, http://dx.doi. org/10.1016/j.jebo.2014.05.004 
Maag, T. (2012). The Role of Media for Inflation Forecast Disagreement of Households and Professional Forecasters. Journal of Money, Credit and Banking, 44(7), 1325-1350, http://dx.doi.org/10.1111/j.1538-4616.2012.00534.x

Lei, C., Lu, Z. Zhang, Z. (2015). News on Inflation and the Epidemiology of Inflation Expectations in China. Economic System, 39(4), 644-653, http://dx.doi.org/doi:10.1016/j. ecosys.2015.04.006

Lucas, R. E. (1972). Expectations and the Neutrality of Money. Journal of Economic Theory, 4(2), 103-124, http://dx.doi.org/10.1016/0022-0531(72)90142-1

Łyziak, T. (2003). Consumer Inflation Expectations in Poland. European Central Bank Working Paper Series, Working Paper No. 287.

(2014). Inflation Expectations in Poland, 2001-2013. Measurement and Economic Testing. National Bank of Poland Working Paper No. 178.

Mankiw, N. G. (1985). Small Business Costs and Large Business Cycles. The Quarterly Journal of Economics', 100(2), 529-538, http://dx.doi.org/10.2307/1885395

Mankiw, N. G., Reis, R. (2002). Sticky Information versus Sticky Prices: A Proposal to Replace the New Keynesian Phillips Curve. The Quarterly Journal of Economics, 117(4), 1661-1710, http://dx.doi.org/10.1162/003355302320935034

Mitchell, J., Weale, M. (2007). The Rationality and Reliability of Expectations Reported by British Households: Micro Evidence from the British Household Panel Survey. Deutsche Bundesbank Discussion Paper Series 1: Economic Studies, No. 19.

Pesaran, M. H., Weale, M. (2005). Survey Expectation. Cambridge Working Papers in Economics No. 0536.

Pfajfar, D., Santoro, E. (2013). News on Inflation and the Epidemiology of Inflation Expectations. Journal of Money, Credit and Banking, 45(6), 1045-1067, http://dx.doi.org/10.1111/ jmcb. 12043

Reis, R. (2006a). Inattentive Consumers. Journal of Monetary Economics, 53(8), 1761-1800, http://dx.doi.org/10.1016/j.jmoneco.2006.03.001

Reis, R. (2006b). Inattentive Producers. Review of Economic Studies, 73(3), 793-821, http://dx.doi. org/10.1111/j.1467-937x.2006.00396.x

Skořepa, M., Kotlán, V. (2003). Assessing Future Inflation in Inflation Targeting: Forecasts or Simulations. Bank for International Settlements Paper No. 19.

Svensson, L. E. O. (1997). Inflation Forecast Targeting: Implementing and Monitoring Inflation Targets. European Economic Review, 41(6), 1111-1146, dx.doi.org/10.1016/ S0014-2921(96)00055-4

(2003). What Is Wrong with Taylor Rules? Using Judgment in Monetary Policy through Targeting Rules. Journal of Economic Literature, 41(2), 426-477, http://dx.doi. org/10.1257/002205103765762734

Szyszko, M. (2011). The Interdependences of Central Bank's Forecasts and Economic Agents Inflation Expectations. Empirical Study. National Bank of Poland Working Paper Series No. 105.

(2015). Inflation Forecast versus Shaping Inflation Expectations. Comparative Analysis. Comparative Economic Research. Central and Eastern Europe, 18(4), 139-156, http://dx.doi.org/10.1515/cer-2015-0033

(forthcoming). Measurement of Inflation Forecast Targeting. A Proposal of Methodological Solution. Economics\&Management. 
Tura, K. (2015). Can Inflation Forecast and Monetary Policy Path be Really Useful? The Case of Czech Republic. Equilibrium. Quarterly Journal of Economy and Economic Policy, 10(3), 9-26, http://dx.doi.org/10.12775/equil.2015.022

Woodford, M. (2012). Forecast Targeting as a Monetary Policy Strategy: Policy Rules in Practice, in Koeing, E. F., Leeson, R., Kahn, G. A. ed., The Taylor Rule and the Transformation of Monetary Policy. Stanford: Hoover Institution Press Publication, pp. 185-234.

Woodford, M. (2003). Interest and Prices. Foundations of Theory of Monetary Policy, Princeton: Princeton University Press.

European Commission (2007). The Joint Harmonised EU Programme of Business and Consumer Surveys, User Guide.

Tomczyk, E. (2010). Analysis of Expectations on the Meso Scale: Use of Contingency Tables, in Stanisławska, E., Tomczyk, E. ed. Inflation Expectations. A View from Various Perspectives. Warsaw: Publishing House of Warsaw School of Economics, pp. 13-42. 